\title{
Exploring Sodium Glucose Co-Transporter-2 (SGLT2) Inhibitors for Organ Protection in COVID-19
}

\author{
Beatriz Fernandez-Fernandez ${ }^{1,2}$, Luis $\mathrm{D}^{\prime}$ Marco $^{3}{ }^{\circledR}$, Jose Luis Górriz ${ }^{3,4}{ }^{\oplus}$, \\ Conxita Jacobs-Cachá ${ }^{2,5}{ }^{\circledR}$, Mehmet Kanbay ${ }^{6}$, Sergio Luis-Lima ${ }^{1,2}$, Esteban Porrini ${ }^{2,7,8}$, \\ Pantelis Sarafidis ${ }^{9}$, María José Soler ${ }^{2,5}$ and Alberto Ortiz ${ }^{1,2, *(1)}$ \\ 1 IIS-Fundación Jiménez Diaz, Department of Medicine, School of Medicine, Universidad Autónoma de Madrid, \\ 28029 Madrid, Spain; BFernandez@fjd.es (B.F.-F.); sergio.lima@quironsalud.es (S.L.-L.) \\ 2 Red de Investigación Renal (REDINREN), Instituto Carlos III-FEDER, 28040 Madrid, Spain; \\ conxita.jacobs@vhir.org (C.J.-C.); esteban.l.porrini@gmail.com (E.P.); m.soler@vhebron.net (M.J.S.) \\ 3 Department of Nephrology, Hospital Clínico Universitario, INCLIVA, 46010 Valencia, Spain; \\ luisgerardodg@hotmail.com (L.D.); jlgorriz@gmail.com (J.L.G.) \\ 4 Medicine Department, Universidad de Valencia, 46010 Valencia, Spain \\ 5 Nephrology Department, Hospital Universitari Vall d'Hebron, Universitat Autònoma de Barcelona, \\ Nephrology Research Group, Vall d'Hebron Research Institute, 08035 Barcelona, Spain \\ 6 Department of Medicine, Division of Nephrology, Koc University School of Medicine, 43010 Istanbul, \\ Turkey; drkanbay@yahoo.com \\ 7 Department of Medicine, Hospital Universitario de Canarias, 38320 Tenerife, Spain \\ 8 Instituto de Tecnologías Biomédicas, University of La Laguna, 38320 Tenerife, Spain \\ 9 Department of Nephrology, Hippokration Hospital, Aristotle University of Thessaloniki, 54642 Thessaloniki, \\ Greece; psarafidis11@yahoo.gr \\ * Correspondence: aortiz@fjd.es; Tel.: +34-91-550-4800
}

Received: 28 May 2020; Accepted: 22 June 2020; Published: 28 June 2020

\begin{abstract}
Hospital admissions and mortality from the Coronavirus disease 2019 (COVID-19) pandemic are spreading throughout the world, and second and third waves are thought to be likely. Risk factors for severe COVID-19 include diabetes, chronic kidney disease and cardiovascular disease. Currently, there is no vaccine and no approved therapy. Therapeutic approaches are aimed at preventing viral replication and spread, limiting the impact of the inflammatory overdrive (cytokine storm), preventing thromboembolic complications and replacing or supporting organ function. However, despite organ support, mortality is currently $65 \%$ for those receiving advanced respiratory support and $78 \%$ for those requiring renal replacement therapies. Thus, efforts should be made to provide adjuvant organ protection therapy. This may imply novel therapies in clinical development (e.g., the Fas ligand trap asunercept), but uptake of repurposed drugs already in clinical use may be faster. In this regard, sodium glucose co-transporter-2 (SGLT2) inhibitors were recently shown to protect the heart and kidney both within and outside of a diabetic milieu context. Further, preclinical data support a beneficial effect for the lung. We now discuss the potential benefits and risks of SGLT2 inhibitors in COVID-19 and an ongoing clinical trial testing the impact of dapagliflozin on outcomes in COVID-19 patients with respiratory failure.
\end{abstract}

Keywords: COVID-19; diabetes; chronic kidney disease; cardiovascular; SGLT2; canagliflozin; dapagliflozin; empagliflozin

\section{Introduction}

Coronavirus disease 2019 (COVID-19) is a pandemic caused by the severe acute respiratory syndrome (SARS)-Coronavirus (CoV)-2. This is the third recent outbreak of coronaviruses following 
the SARS-CoV (2002) and the Middle East respiratory syndrome (MERS)-CoV (2015). It originated from the Chinese city of Wuhan in December 2019 and as of 8 June 2020 has infected more than 7 million people worldwide with more than 400,000 deaths [1-3]. Most common presenting symptoms include fatigue, fever, cough, dyspnea and diarrhea while median time between symptoms onset and death is 14 days [4-6]. The mortality rate of $2.8 \%$ (median age of 75 years) is lower than the $10 \%$ mortality in SARS-CoV and 37\% mortality in MERS-CoV; however, higher absolute numbers of cases and deaths are explained by easy transmission via direct contact or droplets, as well as transmission by asymptomatic or mildly symptomatic individuals [4,7-9]. Although the search of reservoir animals has been inconclusive so far, there is $88 \%$ genetic similarity between SARS-CoV- 2 and two bat-derived coronaviruses [10-12]. Possible fecal-oral transmission has also been reported while vaginal virus delivery has not been proven [13-15].

The estimated mortality of diagnosed cases ranges from $2.3 \%$ to $15.2 \%$, depending on patient populations, diagnostic strategies and, probably, additional poorly characterized factors [16,17]. The need for intensive care unit (ICU) admission is around 20\% [18]. In ICUs, about $90 \%$ require respiratory support via either mechanical $(88 \%)$ or non-invasive ventilation $(12 \%)$ and mortality hovers around $50 \%$ [19]. Older age, higher sequential organ failure assessment (SOFA) score, D-dimer $>1 \mu \mathrm{g} / \mathrm{mL}$, presence of comorbid diseases or secondary infections, elevated inflammatory markers, low CD3+ and CD8 + T cell counts and cardiac troponin $>0.05 \mathrm{ng} / \mathrm{mL}$ predict mortality while acute respiratory failure and fulminant myocarditis are the most commonly reported causes of death [20-22].

Herein, we now review the current status of therapy for COVID-19 emphasizing the concept of organ protection and the potential beneficial role of sodium glucose co-transporter-2 (SGLT2) inhibitors in the COVID-19 context.

\section{Risk Factors for Severe COVID-19}

Clinical conditions associated with a higher risk for severe complications and death in COVID-19 infected patients include cardiovascular disease, diabetes and chronic kidney disease (CKD). A recent meta-analysis including 1527 patients from six different studies, mostly from Wuhan (China), showed that hypertension $(17.1 \%)$, cardiovascular disease $(16.4 \%)$, and diabetes $(9.7 \%)$ were the most prevalent diseases observed in patients with severe COVID-19 complications [23]. The fatality rate was $10.5,7.3$ and $6 \%$ in persons with cardiovascular disease, diabetes and hypertension, respectively, whereas the overall fatality rate was 2.3\% in the COVID-19 summary report of 72,314 cases released by the Chinese Center for Disease Control [24]. Thus, patients with previous cardiovascular disease and diabetes had more severe disease and more complications [25]. Cardiovascular disease and diabetes are closely linked to CKD. In this regard, a meta-analysis of four studies, which included 1389 COVID-19 patients, disclosed that CKD was associated with a severe presentation of the disease (OR, $3.03 ; 95 \% \mathrm{CI}, 1.09-8.47)$, despite none of the individual studies showing this association [26]. The likely explanation may be the higher number of patients analyzed in the meta-analysis. COVID-19 may also be complicated by acute kidney injury (AKI), which developed in $5.1 \%$ of 701 adults in a prospective cohort study [27]. Mortality was higher in patients with elevated than normal serum creatinine at baseline: HR, 2.10; 95\%CI, 1.36-3.26. Additionally, although not prominent in early Wuhan reports, renal disease was the most common comorbidity among the first 6720 reported critically ill COVID-19 patients in the UK, being five-fold more common than cardiovascular disease [28].

\section{Current Therapeutic Approaches to COVID-19}

There is no specific treatment for SARS-CoV-2. Several studies aiming to identify novel therapeutic agents and vaccines against SARS-CoV-2 are ongoing, but their safety and efficacy need to be assessed before generalized use [29-31]. In this emergency context, the health community has initially promoted the off-label use of approved drugs to try to control the SARS-CoV-2 infection as well as to manage the inflammatory, thrombotic, respiratory and cardiovascular complications in critically ill patients (Figure 1). However, therapies aimed at organ protection have lagged behind. 


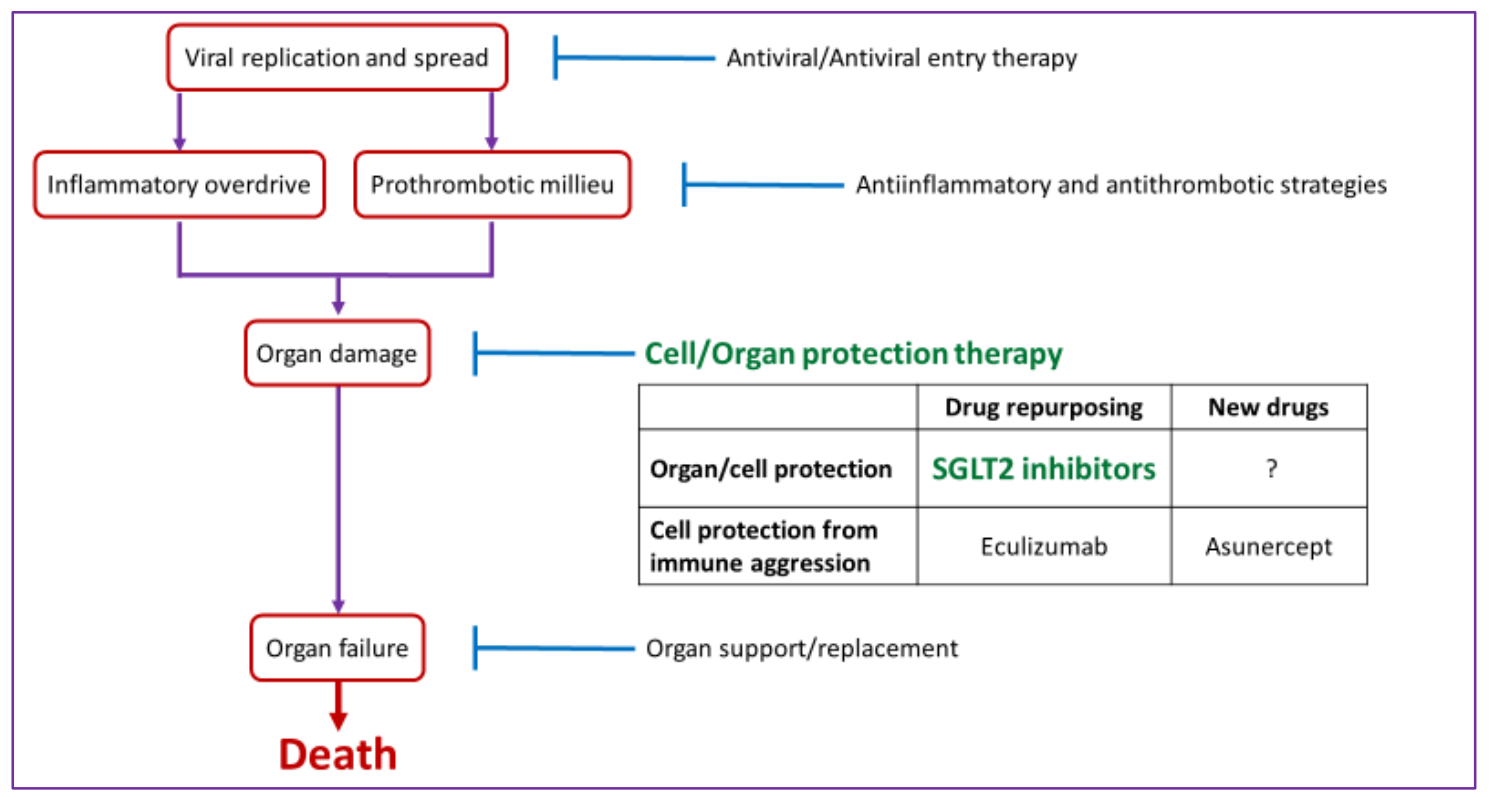

Figure 1. Pathogenic basis of current therapeutic approaches to COVID-19 and potential place of SGLT2 inhibitors.

\subsection{Antiviral Therapies}

The primary goal during the initial phases of SARS-CoV-2 infection is to stop the virus cell cycle and slow down disease progression. The SARS-CoV-2 cell cycle resembles that of other coronaviruses (i.e., SARS-CoV and MERS-CoV) and shares replication mechanisms with other RNA viruses (i.e., HIV or Ebola). Therefore, approved drugs to treat other viral infections or with a potential to interfere in viral propagation mechanism have been tested in COVID-19 patients [29,30,32,33]. Coronaviruses target host cells via direct interaction of the viral spike (S) protein with a cell membrane protein. In particular, SARS-CoV-2, like SARS-CoV, enters host cells via the angiotensin converting enzyme 2 (ACE2), an endocytosis process facilitated by the type 2 transmembrane serine protease (TMPRSS2) [34,35]. A recent preprint report described SARS-CoV-2 entry into host cells by interacting with basigin, also known as extracellular matrix metalloproteinase inducer (EMMPRIN) or cluster of differentiation 147 (CD147) [34]. Once inside cells, viruses promote the translation of their non-essential polyproteins that after proteolysis will form a replication-transcription complex to replicate the genomic RNA and produce viral proteins. Then, new viral particles are assembled and released, starting the cycle again (Figure 2).

The virus-host cell recognition may be prevented by soluble recombinant human ACE2 (rhACE2) or convalescent SARS-CoV-2 sera [36,37]. The potential therapeutic role of rhACE2 for COVID-19 is under study as it decreased SARS-CoV-2 infectivity in human engineered blood vessels and kidney organoids [38,39]. Blocking CD147-mediated virus entry could also be a therapeutic option [40]. Meplazumab, a humanized antibody against CD147, was reported to accelerate COVID-19 resolution in seventeen COVID-19 patients [41]. In addition, viral endocytosis can be inhibited by drugs. Camostat mesylate and nafamostat mesylate are serine protease inhibitors that target TMPRSS2 and block SARS-CoV-2 infection in human lung cells [35,42]. Camostat mesylate is approved in Japan to treat pancreatitis and COVID-19 clinical trials are ongoing [43]. Chloroquine and its hydroxylated form (hydroxychloroquine) were discovered in the early $30^{\prime}$ s and $50^{\prime}$ s, respectively. Both drugs are weak bases that accumulate in acidic compartments such as lysosomes and autosomes, interfering with normal endocytosis processes. Chloroquine was initially developed to treat malaria and hydroxychloroquine to treat rheumatoid arthritis, but they are now approved to treat diseases ranging from cancer to chronic inflammatory diseases [44]. Because of a known safety profile and low cost, they are being tested for both COVID-19 prevention and treatment with encouraging results although their efficacy 
has been questioned [33,45,46]. Arbidol (umifenovir) is a broad-spectrum antiviral drug that blocks the virus-cell membrane fusion by intercalating into membrane lipids $[47,48]$. Its use is approved for influenza treatment in Russia and China, and it is being tested in clinical trials for COVID-19. Wuhan data report better outcomes in patients treated with arbidol alone or in combination with other antiretroviral drugs [49,50]. Drugs that block viral RNA replication include lopinavir/ritonavir and darunavir, which inhibit the viral 3-chymotrypsin-like protease and are second line antiretrovirals for HIV [51]. However, the first randomized clinical trial (RCT) testing Lopinavir/Ritonavir suggested a limited efficacy for SARS-CoV-2 infections [52]. Ribavirin, remdesivir and favipiravir are broad-range viral RNA polymerase blockers that have been previously tested for Hepatitis C, Ebola or Influenza, among others [53-57]. Their efficacy in COVID-19 is currently being tested in several RCTs following the publication of case reports of successful remdesivir or favipiravir use [58-60].

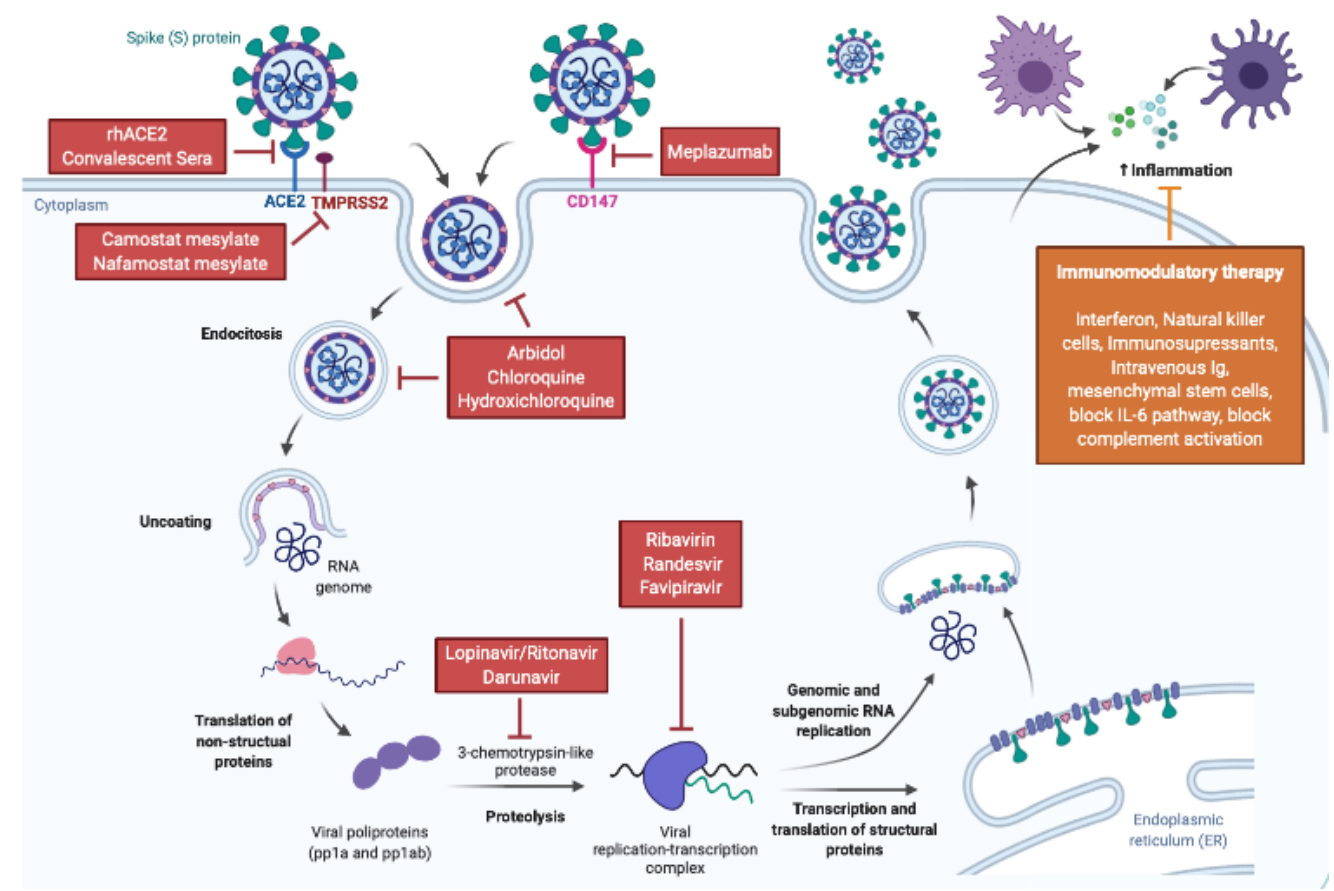

Figure 2. Scheme of the SARS-CoV-2 replication cycle, the host immune response and potential drug targets. This picture shows a simplified SARS-CoV-2 life cycle in the target cells as well as a representation of the immune response against the virus. The targets of antiviral therapies and immunomodulation approaches are highlighted.

\subsection{Anti-Inflammatory Therapies}

In later disease stages, immunomodulation strategies should be considered. Viral infections are met by a regulated immune response aimed at fighting the virus. However, excessive release of proinflammatory cytokines and chemokines may lead to a "cytokine storm", thought to be the main cause of the SARS-CoV-2 acute respiratory distress syndrome, which is associated to thromboembolic events leading to multi-organ failure and death [61,62]. Although immunomodulation therapies remain controversial in the COVID-19 context because they may negatively influence the natural immune response against the virus [63], several ongoing RCTs aim to minimize immune system over-activation [30]. The main immunomodulatory strategies are [29] enhancing innate immune responses by administering recombinant interferon or natural-killer cells and [30] decrease inflammatory responses via the use of corticosteroids and other immunosuppressants, intravenous administration of general or SARS-CoV-2-specific immunoglobulins, infusion of mesenchymal stem cells, and blocking interleukin-1 (anakinra), interleukin-6 (tocilizumab, sarilumab) or complement activation (eculizumab and 5 additional agents are in clinical trials) $[30,64]$. Finally, it has been suggested that extracorporeal 
treatment, for example high-volume hemofiltration, may play a role in patients with COVID 19 and cytokine storm [65].

\subsection{Anti-Thrombotic Strategies}

Classical anticoagulant therapies were initially applied to COVID-19 patients at risk of thrombotic and thromboembolic events [66]. However, since COVID-19 patients with acute respiratory failure present severe hypercoagulability with fibrin formation and polymerization that may predispose to thrombosis and correlates with worse outcome, the use of low molecular weight heparin was extended to patients not requiring admission, especially if there is a high risk of venous thromboembolism (e.g., reduced mobility or co-morbidities), elevated D-dimer ( $>2$ times the upper limit normal) and low risk of bleeding [67].

\subsection{Organ Support, Replacement and Protection}

In some cases, organ failure needs organ replacement or support therapies. The most common are respiratory support (advanced respiratory support was required by $70 \%$ of UK critically ill patients), renal replacement therapies (required in $22 \%$ of these patients) and cardiovascular support [68]. Mortality was $65 \%$ for those receiving advanced respiratory support and $78 \%$ for those requiring renal replacement therapies. The high mortality of patients requiring organ support points to the need to develop and implement organ protective strategies. As an example, Apogenix is to start clinical trials of asunercept (APG101) for COVID-19. This is, a human fusion protein consisting of the extracellular domain of the CD95 (Fas, TNFRSF6) receptor and the Fc domain of an IgG antibody that prevents Fas-induced epithelial cell death. Fas is upregulated in kidney cells during systemic inflammation and promotes lung and kidney cell death $[69,70]$. However, despite potential to protect both lung and kidney, asunercept is still in early stages of clinical development [71]. Drug repurposing offers the possibility of accelerated clinical translation. In this regard, SGLT2 inhibitors were recently shown to have heart and kidney organ protective properties both within and outside of a diabetic milieu context [72-74] and could offer an opportunity for organ protection in COVID-19.

\subsection{SGLT2 Inhibitors: From Glucose Lowering to Organ Protection}

SGLT2 inhibitors are oral hypoglycemic agents for patients with type 2 diabetes mellitus (T2DM) [75]. One member of the class, dapagliflozin, was also recently approved in Europe for patients with T1DM. They block SGLT2, a high-capacity/low-affinity glucose transporter located in the S1 segment of renal proximal tubules and responsible for $90 \%$ of glucose reabsorption [76]. In diabetic patients, SGLT2 expression increases up to 3-fold. However, this effort to preserve glucose by preventing urinary excretion further deranges glucose homeostasis. SGLT2 inhibition results in excretion of $50-60 \%$ of filtered glucose, roughly corresponding to $60-100 \mathrm{~g} / \mathrm{day}$ and loss of the associated calories [76,77].

SGLT2 inhibitors have beneficial metabolic and cardiovascular effects. Loss of glucose in urine results in weight loss of around 2-4 kg within 3-6 months [78]. Further, the double mild natriuretic action (SGLT2 inhibition and the osmotic effect of glucosuria) causes clinically meaningful blood pressure reductions of $4-5 / 2-3 \mathrm{mmHg}$ [79]. SGLT2 inhibition decrease of sodium reabsorption results in decreased energy expenditure by proximal tubular cells, potentially influencing other functions of these metabolically active cells. SGLT2 inhibitors are generally well-tolerated, with the most frequent adverse event being genital mycotic infections and the most serious the rare development of euglycemic diabetic ketoacidosis (DKA) [80].

Accumulating evidence suggest that SGLT2 inhibitors are potent cardioprotective and nephroprotective agents [81]. The Empagliflozin Cardiovascular Outcome Event Trial in Type 2 Diabetes Mellitus Patients (EMPA-REG OUTCOME), which randomized 7020 patients with T2DM and established cardiovascular disease to empagliflozin or placebo, first showed reductions of $14 \%$ in the primary outcome (non-fatal myocardial infarction or stroke, or death from 
cardiovascular causes) (HR, $0.86 ; 95 \% \mathrm{CI}, 0.74-0.99 ; p=0.04$ for superiority), 38\% in cardiovascular death, 35\% in hospitalization for heart failure (HHF) and 32\% in all-cause mortality [82]. The Canagliflozin-Cardiovascular-Assessment-Study (CANVAS) randomized 10,142 T2DM patients with either established cardiovascular disease or multiple cardiovascular risk factors to canagliflozin or placebo and also showed $14 \%$ reduction in the same primary outcome $(\mathrm{HR}, 0.86 ; 95 \% \mathrm{CI}$, $0.75-0.97) ; p=0.02$ for superiority), $33 \%$ reduction in HHF and a non-significant trend towards lower all-cause mortality (HR, 0.87; 95\%CI, 0.74-1.01) [83]. The Multicenter Trial to Evaluate the Effect of Dapagliflozin on the Incidence of Cardiovascular Events Thrombolysis in Myocardial Infarction 58 (DECLARE-TIMI 58) trial included 17,160 patients (10,186 without atherosclerotic cardiovascular disease, i.e., a lower-risk population) and showed non-inferiority of dapagliflozin in the aforementioned primary composite outcome and superiority compared to placebo with regards to HHF (HR, 0.73; 95\%CI, 0.61-0.88) [84]. Finally, the recent DAPAgliflozin in Heart Failure (DAPA-HF) study included 4744 patients (with or without T2DM) with NYHA II-IV heart failure and an ejection fraction $<40 \%$ (heart failure with reduced ejection fraction) and showed that dapagliflozin significantly reduced the primary outcome of worsening heart failure or cardiovascular death (HR, 0.74; 95\%CI, 0.65-0.85) in both diabetic and non-diabetic patients [73,85].

In parallel, preliminary evidence suggested that SGLT2 inhibitors significantly reduce albuminuria in comparison to placebo or active antihyperglycemic agents [86], while all the cardiovascular safety trials (EMPA-REG OUTCOME, CANVAS, DECLARE-TIMI) showed prominent effects on outcomes associated with kidney disease progression $[83,84,87]$. In a meta-analysis of these trials, SGLT2 inhibitors reduced the incidence of the composite renal outcome of worsening renal function (doubling of serum creatinine accompanied by an eGFR of $\leq 45 \mathrm{~mL} / \mathrm{min} / 1.73 \mathrm{~m}^{2}$ ), end-stage renal disease (ESRD) defined as eGFR $<15 \mathrm{~mL} / \mathrm{min} / 1.73 \mathrm{~m}^{2}$ ) or renal death (defined as: "any adjudicated non-CV death event where the adjudication committee assigned a renal proximate cause is considered a renal death") by $45 \%$ (HR, 0.55; 95\%CI, 0.48-0.64) [88]. The recent CREDENCE study in 4401 patients with T2DM and diabetic kidney disease (CKD and albumin-to-creatinine-ratio $300-5000 \mathrm{mg} / \mathrm{g}$ ) was prematurely stopped, showing reductions of $34 \%$ in the composite of ESRD, doubling of serum creatinine, or renal death and 32\% in ESRD with canagliflozin compared to placebo [87]. Recently, the Study to Evaluate the Effect of Dapagliflozin on Renal Outcomes and Cardiovascular Mortality in Patients with Chronic Kidney Disease (DAPA-CKD), a renal outcome trial evaluating the effect of dapagliflozin in patients with diabetic or non-diabetic CKD was also prematurely stopped due to benefit [89].

The use of eGFR as an endpoint has been criticized since there is evidence that SGLT2 may reduce muscle mass and this may be associated with lower serum creatinine values [90]. However, this criticism does not apply to short term studies in which GFR was measured [91], as well as to albuminuria or hard (death) renal endpoints.

Several hypotheses on the mechanisms contributing to the cardioprotective properties of SGLT2 inhibitors were generated, including reductions in glycemia, body weight, visceral adiposity, uric acid, albuminuria, sympathetic tone, a shift from glucose to fatty acid oxidation resulting in increased levels of $\beta$-hydroxybutyrate which is a better cardiac fuel or a direct effect of SGLT2 inhibitors on cardiomyocytes $[92,93]$. However, the dissociation of the curves for the outcomes that displayed the larger differences between groups in these trials (HHF and cardiovascular death) were observed during the first weeks suggesting that hemodynamic mechanisms, including mild natriuresis and reductions in blood pressure, may play a more prominent role [81]. Similarly, anti-inflammatory and antifibrotic effects and reversal of renal hypoxia of these agents could help towards a renoprotective action [94-96], but modulation of renal microcirculation is the most possible renoprotective mechanism [81]. Briefly, DM promotes renal injury through afferent arteriole vasodilation resulting in increased intraglomerular pressure and albuminuria. SGLT2 inhibitors through inhibition of sodium reabsorption in proximal tubules increase its distal availability; this is sensed by the macula densa, which restores the tubuloglomerular feedback resulting in reversal of the vasodilation of the afferent arteriole, decreased intraglomerular pressure and proteinuria $[81,97]$. However, additional potential mechanisms of action remain underexplored. 
Thus, $\beta$-hydroxybutyrate modulates epigenetic regulation of gene expression by promoting histone Lysine $\beta$-hydroxybutyrylation, a histone mark that promotes the expression of cell protective genes such as Ppargc1a (which encodes PGC-1 $\alpha$ ) [97-99].

Based on the above findings, several consensus reports from major international bodies recommend SGLT2 inhibitors as the drug of choice after metformin in patients with T2DM and evidence of atherosclerotic cardiovascular disease, CKD or heart failure [81,100]. Additionally, clinical guidelines are starting to recommend SGLT2 inhibitors for patients with heart failure with reduced ejection fraction with or without diabetes [101,102].

More recently, preclinical studies, although limited to the vasculature, suggest a potential role for SGLT2 inhibitors in lung protection. Thus, in ex vivo studies, canagliflozin relaxed mouse pulmonary arteries in a dose-dependent manner [103]. In rat pulmonary arterial hypertension, empagliflozin improved survival, reduced medial wall thickening and decreased muscularization of pulmonary arterioles [104]. However, the molecular mechanisms of this protective effect remain unclear, despite the observation that empagliflozin was associated with increased apoptosis and decreased proliferation in pulmonary vessels and thus prevented adverse pulmonary arteriole remodeling.

Overall, there is accumulating clinical and preclinical data suggesting that SGLT2 inhibitors have the potential to provide organ protection both inside and outside of the diabetic context.

\section{Current Recommendations and Potential Dangers of SGLT2 Inhibitors during Acute Illness}

During acute illness, care should be taken with volume depletion, blood pressure reduction and DKA when prescribing SGLT2 inhibitors. In the context of COVID-19, there is additionally the potential for interaction with other drugs. In this regard, health agencies (Royal United Hospitals, NHS Foundation, Catalan Health agency, among others) have warned about safety concerns for SLGT2i and the risk of DKA in patients with both diabetes and COVID19 infection. In this setting, they have recommended to avoid SGLT2 inhibitors in all patients with risk factors for developing symptoms or serious complications of COVID-19, such as patients with a history of hypertension, T2DM, atherosclerotic cardiovascular disease, heart failure and/or estimated GFR $<25 \mathrm{~mL} / \mathrm{min} / 1.73 \mathrm{~m}^{2}$. In this regard, COVID-19 patients may decrease food intake and may develop diarrhea and increased insensitive fluid losses through respiration and fever. Nevertheless, there is no published study to support this recommendation. It would probably be necessary to individualize the recommendation to discontinue SGLT2 inhibitors only in COVID-19 infected patients who present symptoms that predispose to a decrease in blood pressure or vascular volume, to avoid both the deterioration of renal function or DKA.

\subsection{Volume Depletion}

SGLT2 inhibitors may cause volume depletion leading to acute kidney injury, usually within well-defined circumstances such as concomitant use of high-dose loop diuretics, low baseline blood pressure, treatment with non-steroidal anti-inflammatory drugs or concomitant digestive problems impairment [86]. Moreover, the glomerular hemodynamic effects of combining renin-angiotensin system (RAS) blockade and SGLT2 inhibitors usually cause a mild decrease in glomerular filtration rate, which is associated with long-term preservation in renal function [105]. Nevertheless, meta-analyses comparing Canagliflozin or Dapagliflozin with either placebo or active comparator and one comparing Empagliflozin with placebo did not confirm a significant volume depletion with SGLT2 inhibitors [106]. In any case, hospitalized patients with mild-moderate manifestations of COVID-19 should be monitored to prevent volume depletion and renal impairment.

\subsection{Blood Pressure}

SGLT2 inhibitors tend to decrease blood pressure due to their osmotic diuretic effect, thus potentially causing orthostatic hypotension and dizziness, especially when combined with diuretics [107]. Other diuresis-independent actions leading to blood pressure reduction, including 
effects on ion transporters, sympathetic nervous system activity, and vascular function, have also been proposed, although clinical evidence supporting these is sparse.

\subsection{Ketoacidosis}

Regulators warn of the risk of DKA, especially in T1DM patients receiving SGLT2 inhibitors, $5 \%$ to $12 \%$ of whom develop DKA [107]. An increased risk of DKA was also recorded in T2DM RCTs of SGLT2 inhibitors [108,109]. In 44,000 patient-years, DKA incidence rates were 0.16-0.76 events per 1000 patient-years for an overall incidence of $<0.1 \%$ of all treated patients [107], and in all cases, a precipitating factor was present. The risk factors for SGLT2 inhibitors-associated DKA are those conditions leading to restricted food intake or severe dehydration, alcohol abuse, sudden reduction in insulin or increased insulin requirements due to acute illness such as low beta cell function reserve (patients with T2DM who have low C-peptide levels, latent autoimmune diabetes in adults (LADA) or a history of pancreatitis) [108]. "Sick day rules" to manage diabetes during intercurrent illness help to prevent future complications [110]. In this regard, patients presenting COVID-19 symptoms may decrease food intake, blood pressure or vascular volume. SGLT2 inhibitors should be discontinued immediately if DKA is suspected or diagnosed since DKA requires urgent hospital admission. Physicians and patients should be aware of early symptoms associated to DKA (thirst, polyuria and sweet, fruity breath, abdominal pain and vomiting) in order to stop them timely.

\subsection{Interactions with Experimental COVID-19 Drugs}

Most interactions of experimental drugs currently used for COVID-19 are related to the potential increased or decreased exposures to or toxicities from co-medication therapies or COVID-19 drugs. In this regard, both hydroxychloroquine and azithromycin prolong the QT interval, and their association may trigger fatal torsade de pointes arrhythmia [111]. The currently known drug interactions can be consulted at https://www.covid19-druginteractions.org/. As of 28 April 2020, no expected interactions for empagliflozin or dapagliflozin were listed, while canagliflozin may potentially interact with lopinavir-ritonavir (Kaletra) requiring monitoring and eventual drug dosing modifications.

\section{Clinical Trials of SGLT2 Inhibitors in COVID-19}

Summarizing the current situation for COVID-19, there is no therapy approved for COVID-19, and current experimental therapies are aimed at preventing viral replication and spread, limiting the impact of the inflammatory overdrive (cytokine storm), preventing thromboembolic complications and replacing or supporting organ function. However, mortality in patients requiring organ support exceeds $60 \%$. Thus, efforts should be made to provide adjuvant organ protection therapies. Despite a potential higher risk for SGLT2 inhibitors adverse effects in the context of acute illness and the resulting current advise against using them in COVID-19 patients, as recently emphasized [112], they have a favorable efficacy profile in preserving renal function, decreasing the impact of heart failure and increasing the survival of patients with risk factors for severe COVID-19. In preclinical studies, SGLT2 inhibitors had lung protective effects by decreasing oxidative stress, tissue hypoxia and inflammation [81,113-115]. Such an uncertainty regarding the use and risk-benefit balance of commonly prescribed drugs is not new in the history of treatment for severe disease or in the COVID-19 context. Beta blockers were contraindicated for many years in patients with heart failure, until RCTs showed benefit. Regarding COVID-19, many physicians rushed to stop RAS blockade in patients with suspected COVID-19 (personal observation) following a hypothesis that these drugs might be detrimental for COVID-19 as in animal models they increase ACE2 (the receptor of SARS-CoV-2) expression in cardiac [116] and vascular tissue [117]. The influence of RAS blockers on lung ACE2 expression is unknown both in experimental models and in humans. On the other hand, the protective effects of ACE2 have been widely described. Thus, an increased expression of ACE2 may be protective rather than detrimental in the COVID-19 context and rhACE2 is being pursued as a potential therapy 
for COVID-19 [118,119]. Clear statements by multiple scientific societies tried to dispel these doubts, supporting continuous use of RAS blockade, unless an established contraindication is met [120-122].

Given the uncertain risk-benefit balance of SGLT2 inhibitors, a clinical trial would be needed to address the issue. In this regard, from 15 April 2020, an ongoing RCT (Dapagliflozin in Respiratory Failure in Patients with COVID-19, DARE-19, NCT04350593) is testing dapagliflozin in patients with COVID-19 and respiratory failure to assess impact on disease progression, complications and all-cause mortality. In this international, multicenter, phase 3 double blind RCT, patients will initiate treatment with dapagliflozin $10 \mathrm{mg}$ or placebo, once a day for 30 days on top of the standard local protocol for COVID19 treatment. The trial will randomize 900 hospitalized COVID-19 patients with mild-moderate disease severity, not needing mechanical ventilator support at the time of screening and having a prior cardiovascular or renal condition that impairs outcomes. Inclusion criteria comprise confirmed SARS-CoV-2 infection with chest radiography or CT scan compatible with COVID-19, mild-moderate disease (SpO2 $\geq 94 \%$ with $\leq 3 \mathrm{~L}$ supplemental oxygen) and at least one of the following conditions: hypertension, T2DM, atherosclerotic cardiovascular disease, heart failure and/or CKD stage 3 to 4 (eGFR $\left.25-60 \mathrm{~mL} / \mathrm{min} / 1.73 \mathrm{~m}^{2}\right)$. Key exclusion criteria include short life expectancy $(<24 \mathrm{~h})$, $\mathrm{SBP}<95 \mathrm{~mm} \mathrm{Hg}$ and/or needing inotropic medication or mechanical circulatory support at screening, T1DM, treatment in the last 14 days or under treatment with anti-immunological drugs for COVID-19, DKA history in the prior 6 months or treatment with any SGLT2 inhibitors at screening or within the prior 4 weeks. The primary endpoint will be time to first occurrence of all-cause mortality or new/worsened organ dysfunction through 30 days of follow up. Organ dysfunction may consist of respiratory decompensation, heart failure, cardiovascular instability, ventricular tachycardia or fibrillation or need for drug or mechanical circulatory support or renal replacement therapy.

A second trial will assess the efficacy of the novel immunomodulatory agent EDP1815 (a strain of Prevotella histicola) and a combination of the approved cardiovascular drugs dapagliflozin and ambrisentan as potential treatments for COVID-19 disease against Standard of Care alone (NCT04393246).

A recent report of the off-label prescription of empagliflozin $10 \mathrm{mg}$ for 5-7 days in three non-diabetic hospitalized patients with severe bilateral interstitial COVID-19-related pneumonia concluded that no favorable action related to treatment was obtained [123]. However, it is unclear how this conclusion may be reached in the absence of controls. The three patients apparently survived, which should be considered a good outcome for a potentially lethal disease.

\section{Conclusions}

SGLT2 inhibitors have shown unexpected clinical benefit regarding heart and kidney protection both within and outside the context of T2DM, suggesting potential intrinsic organ protective effects. This is supported by preclinical data that suggest a range of potential mechanisms of action, not limited to hemodynamic effects. These mechanisms of action may impact cell resistance to diverse stressors by decreasing oxidative stress and inflammation. Thus, SGLT2 inhibitors may be potentially beneficial as organ protective agents in COVID-19 (Table 1). However, given the potential risks of SGLT2 inhibitors in acutely ill patients, any use of these agents for COVID-19 patients with severe disease should be in the context of a clinical trial. Fortunately, results of the ongoing DARE-19 dapagliflozin in respiratory failure trial in patients with COVID-19 are expected by December 2020, thus potentially on time for second or third waves of COVID-19. Additionally, the results of this trial may guide the field of SGLT2 inhibitors in organ protection beyond viral infection or diabetes. 
Table 1. SGLT2 Inhibitors and COVID-19.

\begin{tabular}{|c|c|}
\hline Current Status & Potential for the Future \\
\hline 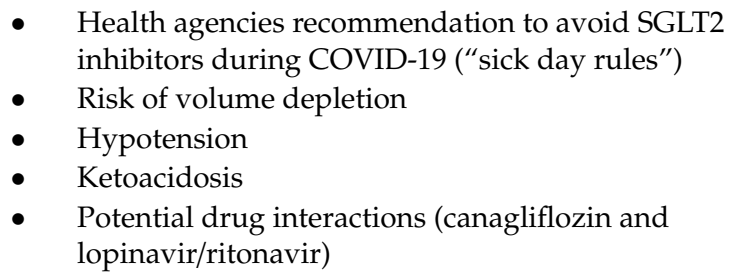 & $\begin{array}{l}\text { - } \\
\text { diabetes and outside diabetes } \\
\text { - } \quad \text { Clinical: heart failure, CKD } \\
\text { - } \quad \text { Preclinical: lung } \\
\text { - Ongoing RCT to assess organ protection } \\
\text { in COVID-19 }\end{array}$ \\
\hline
\end{tabular}

Author Contributions: A.O., conceptualization, writing-original draft preparation; B.F.-F., L.D., J.L.G., C.J.-C., M.K., S.L.-L., E.P., P.S., M.J.S. and A.O., writing-review and editing. All authors have read and agreed to the published version of the manuscript.

Funding: This research received no external funding.

Acknowledgments: Sources of support: FIS/Fondos FEDER (PI17/00257, PI18/01386, PI19/00588, PI19/00815, DTS18/00032, ERA-PerMed-JTC2018 (KIDNEY ATTACK AC18/00064 and PERSTIGAN AC18/00071, ISCIII-RETIC REDinREN RD016/0009), Sociedad Española de Nefrología, FRIAT, Comunidad de Madrid en Biomedicina B2017/BMD-3686 CIFRA2-CM.

Conflicts of Interest: P.S. is an advisor/speaker to Amgen, Astra Zeneca, Bayer, Boehringer Ingelheim, Elpen Pharmaceuticals, Genesis Pharma, Menarini, Innovis Pharma, Winmedica and has received research support for an Investigator-Initiated Study from Astra Zeneca. J.L.G. has served as consultant for Boëhringer-Ingelheim, Mundipharma, AstraZeneca, Novonordisk and has received speaker honoraria from Boëhringer-Ingelheim, Mundipharma, AstraZeneca, Novonordisk, Novartis and Eli Lilly. L.D.M. has no conflict of interest. A.O. is a Consultant for Sanofi Genzyme and had received speaker fees from Shire, Amicus, Amgen, Otsuka, Mundipharma, Fresenius Medical Care, Kyowa-Kirin, Astra-Zeneca, Menarini and directs the Mundipharma-UAM Cátedra de Diabetes y Enfermedad Renal. M.J.S. is a Consultant for NovoNordisk and had received speaker fees from Janssen, Boehringer, Eli Lilly, AstraZeneca, and Esteve. B.F.F. reports speaker fees or travel support from Abbvie, Astrazeneca, Boehringer Ingelheim, Esteve, Menarini, Mundipharma, Novartis and Novonordisk, outside the submitted work.

\section{References}

1. Rothan, H.A.; Byrareddy, S.N. The epidemiology and pathogenesis of coronavirus disease (COVID-19) outbreak. J. Autoimmun. 2020, 109, 102433. [CrossRef]

2. Bogoch, I.I.; Watts, A.; Thomas-Bachli, A.; Huber, C.; Kraemer, M.U.G.; Khan, K. Pneumonia of unknown aetiology in Wuhan, China: Potential for international spread via commercial air travel. J. Travel Med. 2020, 27, taaa008. [CrossRef]

3. Lu, H.; Stratton, C.W.; Tang, Y. Outbreak of pneumonia of unknown etiology in Wuhan, China: The mystery and the miracle. J. Med. Virol. 2020, 92, 401-402. [CrossRef]

4. $\quad$ Ren, L.-L.; Wang, Y.M.; Wu, Z.Q.; Xiang, Z.C.; Guo, L.; Xu, T.; Jiang, Y.Z.; Xiong, Y.; Li, Y.J.; Li, X.W.; et al. Identification of a novel coronavirus causing severe pneumonia in human. Chin. Med. J. 2020, 133, 1015-1024. [CrossRef] [PubMed]

5. Wang, W.; Tang, J.; Wei, F. Updated understanding of the outbreak of 2019 novel coronavirus (2019-nCoV) in Wuhan, China. J. Med. Virol. 2020, 92, 441-447. [CrossRef] [PubMed]

6. Huang, C.; Wang, Y.; Li, X.; Ren, L.; Zhao, J.; Hu, Y.; Zhang, L.; Fan, G.; Xu, J.; Gu, X.; et al. Clinical features of patients infected with 2019 novel coronavirus in Wuhan, China. Lancet 2020, 395, 497-506. [CrossRef]

7. Ahn, D.-G.; Shin, H.-J.; Kim, M.-H.; Lee, S.; Kim, H.-S.; Myoung, J.; Kim, B.-T.; Kim, S.-J. Current status of epidemiology, diagnosis, therapeutics, and vaccines for novel coronavirus disease 2019 (COVID-19). J. Microbiol. Biotechnol. 2020, 30, 313-324. [CrossRef] [PubMed]

8. Bai, Y.; Yao, L.; Wei, T.; Tian, F.; Jin, D.-Y.; Chen, L.; Wang, M. Presumed asymptomatic carrier transmission of COVID-19. JAMA 2020, 323, 1406. [CrossRef] [PubMed]

9. Pan, X.; Chen, D.; Xia, Y.; Wu, X.; Li, T.; Ou, X.; Zhou, L.; Liu, J. Asymptomatic cases in a family cluster with SARS-CoV-2 infection. Lancet Infect. Dis. 2020, 20, 410-411. [CrossRef] 
10. Lu, R.; Zhao, X.; Li, J.; Niu, P.; Yang, B.; Wu, H.; Wang, W.; Song, H.; Huang, B.; Zhu, N.; et al. Genomic characterisation and epidemiology of 2019 novel coronavirus: Implications for virus origins and receptor binding. Lancet 2020, 395, 565-574. [CrossRef]

11. Bassetti, M.; Vena, A.; Giacobbe, D.R. The novel Chinese coronavirus (2019-nCoV) infections: Challenges for fighting the storm. Eur. J. Clin. Investig. 2020, 50, e13209. [CrossRef] [PubMed]

12. Ji, W.; Wang, W.; Zhao, X.; Zai, J.; Li, X. Cross-species transmission of the newly identified coronavirus 2019-nCoV. J. Med. Virol. 2020, 92, 433-440. [CrossRef] [PubMed]

13. Mullins, E.; Evans, D.; Viner, R.M.; O’Brien, P.; Morris, E. Coronavirus in pregnancy and delivery: Rapid review. Ultrasound Obstet. Gynecol. 2020, 55, 586-592. [CrossRef] [PubMed]

14. Parazzini, F.; Bortolus, R.; Mauri, P.A.; Favilli, A.; Gerli, S.; Ferrazzi, E. Delivery in pregnant women infected with SARS-CoV-2: A fast review. Int. J. Gynecol Obs. 2020, 13166.

15. Gu, J.; Han, B.; Wang, J. COVID-19: Gastrointestinal manifestations and potential fecal-oral transmission. Gastroenterology 2020, 158, 1518-1519. [CrossRef]

16. Baud, D.; Qi, X.; Nielsen-Saines, K.; Musso, D.; Pomar, L.; Favre, G. Real estimates of mortality following COVID-19 infection. Lancet Infect. Diseases 2020. [CrossRef]

17. Backer, J.A.; Klinkenberg, D.; Wallinga, J. Incubation period of 2019 novel coronavirus (2019-nCoV) infections among travellers from Wuhan, China. Eurosurveillance 2020, 25, 2000062. [CrossRef]

18. Rodriguez-Morales, A.J.; Cardona-Ospina, J.A.; Gutiérrez-Ocampo, E.; Villamizar-Peña, R.; Holguin-Rivera, Y.; Escalera-Antezana, J.P.; Alvarado-Arnez, L.E.; Bonilla-Aldana, D.K.; Franco-Paredes, C.; Henao-Martinez, A.F.; et al. Clinical, laboratory and imaging features of COVID-19: A systematic review and meta-analysis. Travel Med. Infect. Dis. 2020, 13, 101623. [CrossRef]

19. Grasselli, G.; Zangrillo, A.; Zanella, A.; Antonelli, M.; Cabrini, L.; Castelli, A.; Cereda, D.; Coluccello, A.; Foti, G.; Fumagalli, R.; et al. Baseline Characteristics and Outcomes of 1591 Patients Infected With SARS-CoV-2 Admitted to ICUs of the Lombardy Region, Italy. JAMA 2020, 323, 1574. [CrossRef]

20. Du, R.H.; Liang, L.R.; Yang, C.Q.; Wang, W.; Cao, T.Z.; Li, M.; Guo, G.Y.; Du, J.; Zheng, C.L.; Zhu, Q.; et al. Predictors of mortality for patients with COVID-19 pneumonia caused by SARS-CoV-2: A prospective cohort study. Eur. Respir. J. 2020, 2000524. [CrossRef]

21. Zhou, F.; Yu, T.; Du, R.; Fan, G.; Liu, Y.; Liu, Z.; Xiang, J.; Wang, Y.; Song, B.; Gu, X.; et al. Clinical course and risk factors for mortality of adult inpatients with COVID-19 in Wuhan, China: A retrospective cohort study. Lancet 2020, 395, 1054-1062. [CrossRef]

22. Henry, B.M.; de Oliveira, M.H.S.; Benoit, S.; Plebani, M.; Lippi, G. Hematologic, biochemical and immune biomarker abnormalities associated with severe illness and mortality in coronavirus disease 2019 (COVID-19): A meta-analysis. Clin. Chem. Lab. Med. 2020. [CrossRef] [PubMed]

23. Li, B.; Yang, J.; Zhao, F.; Zhi, L.; Wang, X.; Liu, L.; Bi, Z.; Zhao, Y. Prevalence and impact of cardiovascular metabolic diseases on COVID-19 in China. Clin. Res. Cardiol. 2020, 109, 531-538. [CrossRef]

24. Wu, Z.; McGoogan, J.M. Characteristics of and important lessons from the coronavirus disease 2019 (COVID-19) outbreak in China. JAMA 2020, 323, 1239. [CrossRef]

25. Guan, W.J.; Ni, Z.Y.; Hu, Y.; Liang, W.H.; Ou, C.Q.; He, J.X.; Liu, L.; Shan, H.; Lei, C.L.; Hui, D.S.C.; et al. Clinical characteristics of coronavirus disease 2019 in China. N. Engl. J. Med. 2020. [CrossRef] [PubMed]

26. Henry, B.M.; Lippi, G. Chronic kidney disease is associated with severe coronavirus disease 2019 (COVID-19) infection. Int. Urol. Nephrol. 2020. [CrossRef] [PubMed]

27. Cheng, Y.; Luo, R.; Wang, K.; Zhang, M.; Wang, Z.; Dong, L.; Li, J.; Yao, Y.; Ge, S.; Xu, G. Kidney disease is associated with in-hospital death of patients with COVID-19. Kidney Int. 2020, 97, 829-838. [CrossRef]

28. Khunti, K.; Singh, A.K.; Pareek, M.; Hanif, W. Is ethnicity linked to incidence or outcomes of Covid-19? BMJ 2020, 369, m1548. [CrossRef]

29. Liu, C.; Zhou, Q.; Li, Y.; Garner, L.V.; Watkins, S.P.; Carter, L.J.; Smoot, J.; Gregg, A.C.; Daniels, A.D.; Jervey, S.; et al. Research and development on therapeutic agents and vaccines for COVID-19 and related human coronavirus diseases. ACS Cent. Sci. 2020, 6, 315-331. [CrossRef]

30. Tu, Y.F.; Chien, C.S.; Yarmishyn, A.A.; Lin, Y.Y.; Luo, Y.H.; Lin, Y.T.; Lai, W.Y.; Yang, D.M.; Chou, S.J.; Yang, Y.P.; et al. A review of SARS-CoV-2 and the ongoing clinical trials. Int. J. Mol. Sci. 2020, 21, 2657. [CrossRef] [PubMed]

31. Zhou, Y.; Hou, Y.; Shen, J.; Huang, Y.; Martin, W.; Cheng, F. Network-based drug repurposing for novel coronavirus 2019-nCoV/SARS-CoV-2. Cell Discov. 2020, 6, 14. [CrossRef] [PubMed] 
32. Vanden Eynde, J.J. COVID-19: A brief overview of the discovery clinical trial. Pharmaceuticals 2020, 13, 65. [CrossRef] [PubMed]

33. Sanders, J.M.; Monogue, M.L.; Jodlowski, T.Z.; Cutrell, J.B. Pharmacologic treatments for coronavirus disease 2019 (COVID-19). JAMA 2020. [CrossRef] [PubMed]

34. Wang, K.; Chen, W.; Zhou, Y.-S.; Lian, J.-Q.; Zhang, Z.; Du, P.; Gong, L.; Zhang, Y.; Cui, H.-Y.; Geng, J.-J.; et al. SARS-CoV-2 invades host cells via a novel route: CD147-spike protein. BioRxiv 2020. [CrossRef]

35. Hoffmann, M.; Kleine-Weber, H.; Schroeder, S.; Krüger, N.; Herrler, T.; Erichsen, S.; Schiergens, T.S.; Herrler, G.; $\mathrm{Wu}$, N.-H.; Nitsche, A.; et al. SARS-CoV-2 cell entry depends on ACE2 and TMPRSS2 and is blocked by a clinically proven protease inhibitor. Cell 2020, 181, 271-280. [CrossRef] [PubMed]

36. Ahn, J.Y.; Sohn, Y.; Lee, S.H.; Cho, Y.; Hyun, J.H.; Baek, Y.J.; Jeong, S.J.; Kim, J.H.; Ku, N.S.; Yeom, J.S.; et al. Use of convalescent plasma therapy in two COVID-19 patients with acute respiratory distress syndrome in Korea. J. Korean Med. Sci. 2020, 35, e149. [CrossRef]

37. Shen, C.; Wang, Z.; Zhao, F.; Yang, Y.; Li, J.; Yuan, J.; Wang, F.; Li, D.; Yang, M.; Xing, L.; et al. Treatment of 5 critically ill patients with COVID-19 with convalescent plasma. JAMA 2020, 323, 1582. [CrossRef]

38. Batlle, D.; Wysocki, J.; Satchell, K. Soluble angiotensin-converting enzyme 2: A potential approach for coronavirus infection therapy? Clin. Sci. 2020, 134, 543-545. [CrossRef]

39. Monteil, V.; Kwon, H.; Prado, P.; Hagelkrüys, A.; Wimmer, R.A.; Stahl, M.; Leopoldi, A.; Garreta, E.; Del Pozo, C.H.; Prosper, F.; et al. Inhibition of SARS-CoV-2 infections in engineered human tissues using clinical-grade soluble human ACE2. Cell 2020, 181, 905-913.e7. [CrossRef]

40. Ulrich, H.; Pillat, M.M. CD147 as a target for COVID-19 treatment: Suggested effects of azithromycin and stem cell engagement. Stem Cell Rev. Rep. 2020. [CrossRef]

41. Bian, H.; Zheng, Z.-H.; Wei, D.; Zhang, Z.; Kang, W.-Z.; Hao, C.-Q.; Dong, K.; Xia, J.; Miao, J.-L.; Xie, R.-H.; et al. Meplazumab treats COVID-19 pneumonia: An open-labelled, concurrent controlled add-on clinical trial. MedRxiv 2020. [CrossRef]

42. Hoffmann, M.; Schroeder, S.; Kleine-Weber, H.; Müller, M.A.; Drosten, C.; Pöhlmann, S. Nafamostat mesylate blocks activation of SARS-CoV-2: New treatment option for COVID-19. Antimicrob. Agents Chemother. 2020, 64. [CrossRef] [PubMed]

43. Ramsey, M.L.; Nuttall, J.; Hart, P.A. A phase 1/2 trial to evaluate the pharmacokinetics, safety, and efficacy of NI-03 in patients with chronic pancreatitis: Study protocol for a randomized controlled trial on the assessment of camostat treatment in chronic pancreatitis (TACTIC). Trials 2019, 20, 501. [CrossRef] [PubMed]

44. Schrezenmeier, E.; Dörner, T. Mechanisms of action of hydroxychloroquine and chloroquine: Implications for rheumatology. Nat. Rev. Rheumatol. 2020, 16, 155-166. [CrossRef]

45. Sharma, A. Chloroquine paradox may cause more damage than help fight COVID-19. Microbes Infect. 2020. [CrossRef]

46. Taccone, F.S.; Gorham, J.; Vincent, J.-L. Hydroxychloroquine in the management of critically ill patients with COVID-19: The need for an evidence base. Lancet Respir. Med. 2020. [CrossRef]

47. Pécheur, E.-I.; Borisevich, V.; Halfmann, P.; Morrey, J.D.; Smee, D.F.; Prichard, M.N.; Mire, C.E.; Kawaoka, Y.; Geisbert, T.W.; Polyak, S.J. The synthetic antiviral drug arbidol inhibits globally prevalent pathogenic viruses. J. Virol. 2016, 90, 3086-3092. [CrossRef]

48. Haviernik, J.; Stefanik, M.; Fojtíková, M.; Kali, S.; Tordo, N.; Rudolf, I.; Hubálek, Z.; Eyer, L.; Ruzek, D. Arbidol (Umifenovir): A broad-spectrum antiviral drug that inhibits medically important arthropod-borne flaviviruses. Viruses 2018, 10, 184. [CrossRef] [PubMed]

49. Zhu, Z.; Lu, Z.; Xu, T.; Chen, C.; Yang, G.; Zha, T.; Lu, J.; Xue, Y. Arbidol monotherapy is superior to lopinavir/ritonavir in treating COVID-19. J. Infect. 2020. [CrossRef]

50. Deng, L.; Li, C.; Zeng, Q.; Liu, X.; Li, X.; Zhang, H.; Hong, Z.; Xia, J. Arbidol combined with LPV/r versus LPV/r alone against Corona Virus Disease 2019: A retrospective cohort study. J. Infect. 2020. [CrossRef]

51. Kanters, S.; Socias, M.E.; Paton, N.I.; Vitoria, M.; Doherty, M.; Ayers, D.; Popoff, E.; Chan, K.; Cooper, D.A.; Wiens, M.O.; et al. Comparative efficacy and safety of second-line antiretroviral therapy for treatment of HIV/AIDS: A systematic review and network meta-analysis. Lancet HIV 2017, 4, e433-e441. [CrossRef]

52. Cao, B.; Wang, Y.; Wen, D.; Liu, W.; Wang, J.; Fan, G.; Ruan, L.; Song, B.; Cai, Y.; Wei, M.; et al. A trial of lopinavir-ritonavir in adults hospitalized with severe Covid-19. N. Engl. J. Med. 2020. [CrossRef] [PubMed]

53. Furuta, Y.; Komeno, T.; Nakamura, T. Favipiravir (T-705), a broad spectrum inhibitor of viral RNA polymerase. Proc. Jpn. Acad. Ser. B: Phys. Biol. Sci. 2017, 93, 449-463. [CrossRef] [PubMed] 
54. Takashita, E. Influenza polymerase inhibitors: Mechanisms of action and resistance. Cold Spring Harb. Perspect. Med. 2020. [CrossRef]

55. Gordon, C.J.; Tchesnokov, E.P.; Woolner, E.; Perry, J.K.; Feng, J.Y.; Porter, D.P.; Götte, M. Remdesivir is a direct-acting antiviral that inhibits RNA-dependent RNA polymerase from severe acute respiratory syndrome coronavirus 2 with high potency. J. Biol. Chem. 2020, 295, 6785-6797. [CrossRef]

56. Hoenen, T.; Groseth, A.; Feldmann, H. Therapeutic strategies to target the Ebola virus life cycle. Nat. Rev. Microbiol. 2019, 17, 593-606. [CrossRef]

57. Zajacc, M.; Muszalska-Kolos, I.; Sobczak, A.; Dadej, A.; Tomczak, S.; Jelińska, A. Hepatitis C-New drugs and treatment prospects. Eur. J. Med. Chem. 2019, 165, 225-249. [CrossRef]

58. Holshue, M.L.; DeBolt, C.; Lindquist, S.; Lofy, K.H.; Wiesman, J.; Bruce, H.; Spitters, C.; Ericson, K.; Wilkerson, S.; Tural, A.; et al. First case of 2019 novel coronavirus in the United States. N. Engl. J. Med. 2020, 382, 929-936. [CrossRef]

59. Kujawski, S.A.; Wong, K.K.; Collins, J.P.; Epstein, L.; Killerby, M.E.; Midgley, C.M.; Abedi, G.R.; Ahmed, N.S.; Almendares, O.; Alvarez, F.N.; et al. First 12 patients with coronavirus disease 2019 (COVID-19) in the United States. MedRxiv 2020. [CrossRef]

60. Wang, Y.; Zhang, D.; Du, G.; Du, R.; Zhao, J.; Jin, Y.; Fu, S.; Gao, L.; Cheng, Z.; Lu, Q.; et al. Remdesivir in adults with severe COVID-19: A randomised, double-blind, placebo-controlled, multicentre trial. Lancet 2020. [CrossRef]

61. Ye, Q.; Wang, B.; Mao, J. The pathogenesis and treatment of the 'Cytokine Storm' in COVID-19. J. Infect. 2020. [CrossRef] [PubMed]

62. Mehta, P.; McAuley, D.F.; Brown, M.; Sanchez, E.; Tattersall, R.S.; Manson, J.J. COVID-19: Consider cytokine storm syndromes and immunosuppression. Lancet 2020, 395, 1033-1034. [CrossRef]

63. Ritchie, A.I.; Singanayagam, A. Immunosuppression for hyperinflammation in COVID-19: A double-edged sword? Lancet 2020, 395, 1111. [CrossRef]

64. Magro, C.; Mulvey, J.J.; Berlin, D.; Nuovo, G.; Salvatore, S.; Harp, J.; Baxter-Stoltzfus, A.; Laurence, J. Complement associated microvascular injury and thrombosis in the pathogenesis of severe COVID-19 infection: A report of five cases. Transl. Res. 2020, 220, 1-13. [CrossRef]

65. Ma, J.; Xia, P.; Zhou, Y.; Liu, Z.; Zhou, X.; Wang, J.; Li, T.; Yan, X.; Chen, L.; Zhang, S.; et al. Potential effect of blood purification therapy in reducing cytokine storm as a late complication of critically ill COVID-19. Clin. Immunol. 2020, 214, 108408. [CrossRef]

66. Bikdeli, B.; Madhavan, M.V.; Jimenez, D.; Chuich, T.; Dreyfus, I.; Driggin, E.; Der Nigoghossian, C.; Ageno, W.; Madjid, M.; Guo, Y.; et al. COVID-19 and thrombotic or thromboembolic disease: Implications for prevention, antithrombotic therapy, and follow-up. J. Am. Coll. Cardiol. 2020, 75, 2950-2973. [CrossRef] [PubMed]

67. Spiezia, L.; Boscolo, A.; Poletto, F.; Cerruti, L.; Tiberio, I.; Campello, E.; Navalesi, P.; Simioni, P. COVID-19-related severe hypercoagulability in patients admitted to intensive care unit for acute respiratory failure. Thromb. Haemost. 2020, 120, 998-1000. [CrossRef]

68. Report on COVID-19 in Critical Care. Available online: https://www.icnarc.org/About/Latest-News/2020/03/ 22/Report-On-196-Patients-Critically-Ill-With-Covid-19 (accessed on 28 May 2020).

69. Ortiz, A.; Danoff, T.M.; Kalluri, R.; González-Cuadrado, S.; Karp, S.L.; Elkon, K.; Egido, J.; Neilson, E.G. Regulation of Fas and Fas ligand expression in cultured murine renal cells and in the kidney during endotoxemia. Am. J. Physiol. Physiol. 1996, 271, F1193-F1201. [CrossRef]

70. Lorz, C.; Ortiz, A.; Justo, P.; González-Cuadrado, S.; Duque, N.; Gómez-Guerrero, C.; Egido, J. Proapoptotic Fas ligand is expressed by normal kidney tubular epithelium and injured glomeruli. J. Am. Soc. Nephrol. 2000, 11, 1266-1277.

71. Boch, T.; Luft, T.; Metzgeroth, G.; Mossner, M.; Jann, J.-C.; Nowak, D.; La Meir, F.; Schumann, C.; Klemmer, J.; Brendel, S.; et al. Safety and efficacy of the CD95-ligand inhibitor asunercept in transfusion-dependent patients with low and intermediate risk MDS. Leuk. Res. 2018, 68, 62-69. [CrossRef]

72. Herrington, W.G.; Preiss, D.; Haynes, R.; Von Eynatten, M.; Staplin, N.; Hauske, S.J.; George, J.T.; Green, J.B.; Landray, M.J.; Baigent, C.; et al. The potential for improving cardio-renal outcomes by sodium-glucose co-transporter-2 inhibition in people with chronic kidney disease: A rationale for the EMPA-KIDNEY study. Clin. Kidney J. 2018, 11, 749-761. [CrossRef] [PubMed] 
73. McMurray, J.J.; Solomon, S.D.; Inzucchi, S.E.; Køber, L.; Kosiborod, M.N.; Martinez, F.A.; Ponikowski, P.; Sabatine, M.S.; Anand, I.S.; Bělohlávek, J.; et al. Dapagliflozin in patients with heart failure and reduced ejection fraction. N. Engl. J. Med. 2019, 381, 1995-2008. [CrossRef] [PubMed]

74. Fernandez-Fernandez, B.; Fernandez-Prado, R.; Górriz, J.L.; Martinez-Castelao, A.; Navarro-González, J.F.; Porrini, E.; Soler, M.J.; Ortiz, A. Canagliflozin and renal events in diabetes with established nephropathy clinical evaluation and study of diabetic nephropathy with Atrasentan: What was learned about the treatment of diabetic kidney disease with canagliflozin and atrasentan? Clin. Kidney J. 2019, 12, 313-321. [CrossRef]

75. Loutradis, C.; Papadopoulou, E.; Angeloudi, E.; Karagiannis, A.; Sarafidis, P. The beneficial actions of SGLT-2 inhibitors beyond management of hyperglycemia. Curr. Med. Chem. 2019, 26. [CrossRef] [PubMed]

76. Ferrannini, E. Sodium-glucose co-transporters and their inhibition: Clinical physiology. Cell Metab. 2017, 26, 27-38. [CrossRef] [PubMed]

77. Novikov, A.; Vallon, V. Sodium glucose cotransporter 2 inhibition in the diabetic kidney. Curr. Opin. Nephrol. Hypertens. 2016, 25, 50-58. [CrossRef]

78. Lee, P.C.; Ganguly, S.; Goh, S.-Y. Weight loss associated with sodium-glucose cotransporter-2 inhibition: A review of evidence and underlying mechanisms. Obes. Rev. 2018, 19, 1630-1641. [CrossRef]

79. Imprialos, K.P.; Sarafidis, P.A.; Karagiannis, A.I. Sodium-glucose cotransporter-2 inhibitors and blood pressure decrease. J. Hypertens. 2015, 33, 2185-2197. [CrossRef]

80. Barski, L.; Eshkoli, T.; Brandstaetter, E.; Jotkowitz, A. Euglycemic diabetic ketoacidosis. Eur. J. Intern. Med. 2019, 63, 9-14. [CrossRef]

81. Sarafidis, P.; Ferro, C.J.; Morales, E.; Ortiz, A.; Malyszko, J.; Hojs, R.; Khazim, K.; Ekart, R.; Valdivielso, J.; Fouque, D.; et al. SGLT-2 inhibitors and GLP-1 receptor agonists for nephroprotection and cardioprotection in patients with diabetes mellitus and chronic kidney disease. A consensus statement by the EURECA-m and the DIABESITY working groups of the ERA-EDTA. Nephrol. Dial. Transplant. 2019, 34, 208-230. [CrossRef]

82. Zinman, B.; Wanner, C.; Lachin, J.M.; Fitchett, D.; Bluhmki, E.; Hantel, S.; Mattheus, M.; Devins, T.; Johansen, O.E.; Woerle, H.J.; et al. Empagliflozin, cardiovascular outcomes, and mortality in type 2 diabetes. N. Engl. J. Med. 2015, 373, 2117-2128. [CrossRef] [PubMed]

83. Neal, B.; Perkovic, V.; Mahaffey, K.W.; De Zeeuw, D.; Fulcher, G.; Erondu, N.; Shaw, W.; Law, G.; Desai, M.; Matthews, D.R.; et al. Canagliflozin and cardiovascular and renal events in type 2 diabetes. N. Engl. J. Med. 2017, 377, 644-657. [CrossRef] [PubMed]

84. Baglioni, P.; Wiviott, S.D.; Raz, I.; Sabatine, M.S.; Akinci, B. Dapagliflozin and cardiovascular outcomes in type 2 diabetes. N. Engl. J. Med. 2019, 380, 1880-1881. [PubMed]

85. Petrie, M.C.; Verma, S.; Docherty, K.F.; Inzucchi, S.E.; Anand, I.; Belohlávek, J.; Böhm, M.; Chiang, C.-E.; Chopra, V.K.; De Boer, R.A.; et al. Effect of dapagliflozin on worsening heart failure and cardiovascular death in patients with heart failure with and without diabetes. JAMA 2020, 323, 1353. [CrossRef]

86. Piperidou, A.; Sarafidis, P.; Boutou, A.; Thomopoulos, C.; Loutradis, C.; Alexandrou, M.E.; Tsapas, A.; Karagiannis, A. The effect of SGLT-2 inhibitors on albuminuria and proteinuria in diabetes mellitus. J. Hypertens. 2019, 37, 1334-1343. [CrossRef]

87. Perkovic, V.; De Zeeuw, D.; Mahaffey, K.W.; Fulcher, G.; Erondu, N.; Shaw, W.; Barrett, T.D.; Weidner-Wells, M.; Deng, H.; Matthews, D.R.; et al. Canagliflozin and renal outcomes in type 2 diabetes: Results from the CANVAS Program randomised clinical trials. Lancet Diabetes Endocrinol. 2018, 6, 691-704. [CrossRef]

88. Zelniker, T.A.; Wiviott, S.D.; Raz, I.; Im, K.; Goodrich, E.; Bonaca, M.P.; Mosenzon, O.; Kato, E.T.; Cahn, A.; Furtado, R.H.M.; et al. SGLT2 inhibitors for primary and secondary prevention of cardiovascular and renal outcomes in type 2 diabetes: A systematic review and meta-analysis of cardiovascular outcome trials. Lancet 2019, 393, 31-39. [CrossRef]

89. Farxiga Is the First SGLT2 Inhibitor to Show Meaningful Benefit in Patients with Chronic Kidney Disease in a Trial Including both Type-2 Diabetics and Non-Diabetics. Available online: https://www.astrazeneca.com/media-centre/press-releases/2020/farxiga-phase-iii-dapa-ckd-trial-will-bestopped-early-after-overwhelming-efficacy-in-patients-with-chronic-kidney-disease.html (accessed on 28 May 2020).

90. Post, A.; Groothof, D.; Eisenga, M.F.; Bakker, S.J.L. Sodium-glucose cotransporter 2 inhibitors and kidney outcomes: True renoprotection, loss of muscle mass or both? J. Clin. Med. 2020, 9, 1603. [CrossRef] 
91. Cherney, D.Z.I.; Perkins, B.A.; Soleymanlou, N.; Maione, M.; Lai, V.; Lee, A.; Fagan, N.M.; Woerle, H.J.; Johansen, O.E.; Broedl, U.C.; et al. Renal hemodynamic effect of sodium-glucose cotransporter 2 inhibition in patients with type 1 diabetes mellitus. Circulation 2013, 129, 587-597. [CrossRef]

92. Uthman, L.; Baartscheer, A.; Bleijlevens, B.; Schumacher, C.A.; Fiolet, J.W.T.; Koeman, A.; Jancev, M.; Hollmann, M.W.; Weber, N.C.; Coronel, R.; et al. Class effects of SGLT2 inhibitors in mouse cardiomyocytes and hearts: Inhibition of $\mathrm{Na}+\mathrm{H}+$ exchanger, lowering of cytosolic $\mathrm{Na}+$ and vasodilation. Diabetologia 2018, 61, 722-726. [CrossRef]

93. Marx, N.; McGuire, D.K. Sodium-glucose cotransporter-2 inhibition for the reduction of cardiovascular events in high-risk patients with diabetes mellitus. Eur. Heart J. 2016, 37, 3192-3200. [CrossRef]

94. García-Carro, C.; Vergara, A.; Agraz, I.; Soler, M.J.; Espinel, E.; Seron, D.; Soler, M.J. The new era for reno-cardiovascular treatment in type 2 diabetes. J. Clin. Med. 2019, 8, 864. [CrossRef] [PubMed]

95. Górriz, J.L.; Navarro-González, J.F.; Ortiz, A.; Vergara, A.; Nuñez, J.; Jacobs-Cachá, C.; Martínez-Castelao, A.; Soler, M.J. Sodium-glucose cotransporter 2 inhibition: Towards an indication to treat diabetic kidney disease. Nephrol. Dial. Transplant. 2020, 35, i13-i23. [CrossRef] [PubMed]

96. Vergara, A.; Jacobs-Cachá, C.; Soler, M.J. Sodium-glucose cotransporter inhibitors: Beyond glycaemic control. Clin. Kidney J. 2019, 12, 322-325. [CrossRef] [PubMed]

97. Zhang, H.; Tang, K.; Ma, J.; Zhou, L.; Liu, J.; Zeng, L.; Zhu, L.; Xu, P.; Chen, J.; Wei, K.; et al. Ketogenesis-generated $\beta$-hydroxybutyrate is an epigenetic regulator of CD8+ T-cell memory development. Nature 2019, 22, 18-25. [CrossRef] [PubMed]

98. Fontecha-Barriuso, M.; Martín-Sánchez, D.; Martinez-Moreno, J.M.; Carrasco, S.; Ruiz-Andrés, O.; Monsalve, M.; Sanchez-Ramos, C.; Gómez, M.J.; Ruiz-Ortega, M.; Sanchez-Niño, M.D.; et al. PGC-1 $\alpha$ deficiency causes spontaneous kidney inflammation and increases the severity of nephrotoxic AKI. J. Pathol. 2019, 249, 65-78. [CrossRef]

99. Andres, O.R.; Suárez-Álvarez, B.; Sanchez-Ramos, C.; Monsalve, M.; Sanchez-Niño, M.D.; Ruiz-Ortega, M.; Egido, J.; Ortiz, A.; Sanz, A.; Ortiz, A. The inflammatory cytokine TWEAK decreases PGC-1 $\alpha$ expression and mitochondrial function in acute kidney injury. Kidney Int. 2016, 89, 399-410. [CrossRef]

100. Aminian, A.; Zajichek, A.; Arterburn, D.E.; Wolski, K.E.; Brethauer, S.A.; Schauer, P.R.; Nissen, S.E.; Kattan, M.W. Erratum. Predicting 10-year risk of end-organ complications of type 2 diabetes with and without metabolic surgery: A machine learning approach. Diabetes Care 2020; 43: 852-859. Diabetes Care 2020, 43, 1367. [CrossRef]

101. Seferović, P.M.; Coats, A.J.; Ponikowski, P.; Filippatos, G.; Huelsmann, M.; Jhund, P.S.; Polovina, M.M.; Komajda, M.; Seferović, J.; Sari, I.; et al. European Society of Cardiology/Heart Failure Association position paper on the role and safety of new glucose-lowering drugs in patients with heart failure. Eur. J. Heart Fail. 2020, 22, 196-213. [CrossRef]

102. O'Meara, E.; McDonald, M.; Chan, M.; Ducharme, A.; Ezekowitz, J.A.; Giannetti, N.; Grzeslo, A.; Heckman, G.A.; Howlett, J.G.; Koshman, S.L.; et al. CCS/CHFS Heart Failure Guidelines: Clinical trial update on functional mitral regurgitation, SGLT2 inhibitors, ARNI in HFpEF, and Tafamidis in Amyloidosis. Can. J. Cardiol. 2020, 36, 159-169. [CrossRef]

103. Han, Y.; Cho, Y.-E.; Ayon, R.; Guo, R.; Youssef, K.D.; Pan, M.; Dai, A.; Yuan, J.X.-J.; Makino, A. SGLT inhibitors attenuate NO-dependent vascular relaxation in the pulmonary artery but not in the coronary artery. Am. J. Physiol. Cell. Mol. Physiol. 2015, 309, L1027-L1036. [CrossRef] [PubMed]

104. Chowdhury, B.; Luu, A.Z.; Luu, V.Z.; Kabir, M.G.; Pan, Y.; Teoh, H.; Quan, A.; Sabongui, S.; Al-Omran, M.; Bhatt, D.L.; et al. The SGLT2 inhibitor empagliflozin reduces mortality and prevents progression in experimental pulmonary hypertension. Biochem. Biophys. Res. Commun. 2020, 524, 50-56. [CrossRef] [PubMed]

105. Diabetes Tipo 2 en Prevención Secundaria. Recomendaciones de Tratamiento Con la Colaboración de MONOGRAFÍAS. Available online: www.cedro.org (accessed on 28 May 2020).

106. Tentolouris, A.; Vlachakis, P.; Tzeravini, E.; Eleftheriadou, I.; Tentolouris, N. SGLT2 inhibitors: A review of their antidiabetic and cardioprotective effects. Int. J. Environ. Res. Public Health 2019, 16, 2965. [CrossRef] [PubMed]

107. Goldenberg, R.; Berard, L.; Cheng, A.; Gilbert, J.D.; Verma, S.; Woo, V.C.; Yale, J.-F. SGLT2 inhibitor-associated diabetic ketoacidosis: Clinical review and recommendations for prevention and diagnosis. Clin. Ther. 2016, 38, 2654-2664.e1. [CrossRef] [PubMed] 
108. Erondu, N.; Desai, M.; Ways, K.; Meininger, G. Diabetic ketoacidosis and related events in the canaglif lozin type 2 diabetes clinical program. Diabetes Care 2015, 38, 1680-1686. [CrossRef] [PubMed]

109. Singh, A.K. Sodium-glucose co-transporter-2 inhibitors and euglycemic ketoacidosis: Wisdom of hindsight. Indian J. Endocrinol. Metab. 2015, 19, 722-730. [CrossRef]

110. Down, S. How to advise on sick day rules. Diabetes Primary Care 2018, 20, 15-16.

111. Roden, D.M.; Harrington, R.A.; Poppas, A.; Russo, A.M. Considerations for drug interactions on QTc interval in exploratory COVID-19 treatment. Hear. Rhythm. 2020. [CrossRef]

112. Chatterjee, S. SGLT-2 inhibitors for COVID-19-A miracle waiting to happen or just another beat around the bush? Prim. Care Diabetes 2020. [CrossRef]

113. Packer, M. Role of impaired nutrient and oxygen deprivation signaling and deficient autophagic flux in diabetic CKD development: Implications for understanding the effects of sodium-glucose cotransporter 2-inhibitors. J. Am. Soc. Nephrol. 2020, 31, 907-919. [CrossRef]

114. Tanaka, A.; Node, K. Exploration of the clinical benefits of sodium glucose co-transporter 2 inhibitors in diabetic patients with concomitant heart failure. Cardiovasc. Diabetol. 2018, 17, 74. [CrossRef] [PubMed]

115. Esterline, R.L.; Vaag, A.; Oscarsson, J.; Vora, J. Mechanisms in endocrinology: SGLT2 inhibitors: Clinical benefits by restoration of normal diurnal metabolism? Eur. J. Endocrinol. 2018, 178, R113-R125. [CrossRef] [PubMed]

116. Ocaranza, M.P.; Godoy, I.; Jalil, J.E.; Varas, M.; Collantes, P.; Pinto, M.; Roman, M.; Ramirez, C.; Copaja, M.; Diaz-Araya, G.; et al. Enalapril attenuates downregulation of angiotensin-converting enzyme 2 in the late phase of ventricular dysfunction in myocardial infarcted rat. Hypertension 2006, 48, 572-578. [CrossRef] [PubMed]

117. Soler, M.J.; Ye, M.; Wysocki, J.; William, J.; Lloveras, J.; Batlle, D. Localization of ACE2 in the renal vasculature: Amplification by angiotensin II type 1 receptor blockade using telmisartan. Am. J. Physiol. Physiol. 2009, 296, F398-F405. [CrossRef]

118. Watkins, J. Preventing a covid-19 pandemic. BMJ 2020, 368. [CrossRef] [PubMed]

119. Zheng, Y.-Y.; Ma, Y.-T.; Zhang, J.-Y.; Xie, X. COVID-19 and the cardiovascular system. Nat. Rev. Cardiol. 2020, 17, 259-260. [CrossRef]

120. Vaduganathan, M.; Vardeny, O.; Michel, T.; McMurray, J.J.; Pfeffer, M.A.; Solomon, S.D. Renin-angiotensin-aldosterone system inhibitors in patients with Covid-19. N. Engl. J. Med. 2020, 382, 1653-1659. [CrossRef] [PubMed]

121. Mancia, G.; Rea, F.; Ludergnani, M.; Apolone, G.; Corrao, G. Renin-angiotensin-aldosterone system blockers and the risk of covid-19. N. Engl. J. Med. 2020, 382, 2431-2440. [CrossRef] [PubMed]

122. Mehra, M.R.; Desai, S.S.; Kuy, S.; Henry, T.D.; Patel, A.N. Cardiovascular disease, drug therapy, and mortality in Covid-19. N. Engl. J. Med. 2020, 382, e102. [CrossRef]

123. Bossi, A.C.; Forloni, F.; Colombelli, P.L. Lack of efficacy of SGLT2-i in severe pneumonia related to novel coronavirus (nCoV) infection: No little help from our friends. Diabetes Ther. 2020. [CrossRef]

(C) 2020 by the authors. Licensee MDPI, Basel, Switzerland. This article is an open access article distributed under the terms and conditions of the Creative Commons Attribution (CC BY) license (http://creativecommons.org/licenses/by/4.0/). 